\title{
Identification and quantification of particle growth channels during new particle formation
}

\author{
M. R. Pennington ${ }^{1}$, B. R. Bzdek ${ }^{1}$, J. W. DePalma ${ }^{1}$, J. N. Smith ${ }^{2,3}$, A.-M. Kortelainen ${ }^{3}$, L. Hildebrandt Ruiz ${ }^{2, *}$, \\ T. Petäjä ${ }^{4}$, M. Kulmala ${ }^{4}$, D. R. Worsnop ${ }^{4}$, and M. V. Johnston ${ }^{1, *}$ \\ ${ }^{1}$ Department of Chemistry and Biochemistry, University of Delaware, Newark, Delaware 19716, USA \\ ${ }^{2}$ Atmospheric Chemistry Division, National Center for Atmospheric Research, 1850 Table Mesa Dr., Boulder, Colorado \\ 80305, USA \\ ${ }^{3}$ Department of Applied Physics, University of Eastern Finland, 70211 Kuopio , Finland \\ ${ }^{4}$ Department of Physical Sciences, University of Helsinki, 00014 Helsinki, Finland \\ * now at: Department of Chemical Engineering, University of Texas at Austin, Austin, Texas 78712, USA
}

Correspondence to: M. V. Johnston (mvj@udel.edu)

Received: 5 March 2013 - Published in Atmos. Chem. Phys. Discuss.: 30 May 2013

Revised: 11 September 2013 - Accepted: 12 September - Published: 17 October 2013

\begin{abstract}
Atmospheric new particle formation (NPF) is a key source of ambient ultrafine particles that may contribute substantially to the global production of cloud condensation nuclei $(\mathrm{CCN})$. While NPF is driven by atmospheric nucleation, its impact on $\mathrm{CCN}$ concentration depends strongly on atmospheric growth mechanisms since the growth rate must exceed the loss rate due to scavenging in order for the particles to reach the CCN size range. In this work, chemical composition measurements of $20 \mathrm{~nm}$ diameter particles during NPF in Hyytiälä, Finland, in March-April 2011 permit identification and quantitative assessment of important growth channels. In this work we show the following: (A) sulfuric acid, a key species associated with atmospheric nucleation, accounts for less than half of particle mass growth during this time period; (B) the sulfate content of a growing particle during NPF is quantitatively explained by condensation of gas-phase sulfuric acid molecules (i.e., sulfuric acid uptake is collision-limited); (C) sulfuric acid condensation substantially impacts the chemical composition of preexisting nanoparticles before new particles have grown to a size sufficient to be measured; (D) ammonium and sulfate concentrations are highly correlated, indicating that ammonia uptake is driven by sulfuric acid uptake; (E) sulfate neutralization by ammonium does not reach the predicted thermodynamic end point, suggesting that a barrier exists for ammonia uptake; (F) carbonaceous matter accounts for more than half of the particle mass growth, and its oxygen-to-carbon ratio
\end{abstract}

$(\sim 0.5)$ is characteristic of freshly formed secondary organic aerosol; and $(\mathrm{G})$ differences in the overall growth rate from one formation event to another are caused by variations in the growth rates of all major chemical species, not just one individual species.

\section{Introduction}

Atmospheric new particle formation (NPF), the process whereby gaseous precursors nucleate to form clusters on the order of one nanometer and then grow rapidly to larger sizes, can significantly impact cloud condensation nuclei $(\mathrm{CCN})$ levels (Kerminen et al., 2005; Kuang et al., 2010; Merikanto et al., 2009) and thereby influence precipitation patterns (Lee and Feingold, 2010) and climate (Rosenfeld et al., 2008) through changing cloud albedo (Charlson et al., 1992; Lohmann and Feichter, 2005). With respect to human health, NPF produces a large number of nanoparticles, and because of their small size they can deposit throughout the respiratory tract or enter the bloodstream (Oberdörster et al., 2005). Exposure to elevated nanoparticle concentrations is associated with higher incidences of adverse cardiopulmonary effects (Gong et al., 2008; Knibbs et al., 2011; Maudgalya et al., 2008). In urban environments, nanoparticles arising from secondary sources can account for over $50 \%$ of the nanoparticle number concentration (Klems et 
al., 2011). Anthropogenic pollution has been suggested to enhance the formation of nanoparticles over forested environments (Zhang et al., 2009). Despite the importance of nanoparticles to climate and human health, the exact mechanisms governing NPF are poorly understood (Bzdek and Johnston, 2010; Kulmala et al., 2004).

Atmospheric NPF is a two-step process involving (1) the nucleation of small particles or clusters at a critical size and (2) spontaneous growth of the critical nucleus to larger sizes (Kulmala et al., 2000; Zhang et al., 2012; Kulmala et al., 2013). Much effort has been devoted to understanding the atmospheric nucleation process. Nucleation is thought to occur mainly by the formation of uncharged clusters in the atmosphere (Kulmala et al., 2007) and involves sulfuric acid (Sipila et al., 2010; Young et al., 2008; Weber et al., 1997), water, ammonia (Ball et al., 1999; Benson et al., 2009; Korhonen et al., 1999), amines (Berndt et al., 2010; Yu et al., 2012; Zollner et al., 2012) and possibly organic condensable species (Metzger et al., 2010) such as organic acids (R. Y. Zhang et al., 2004; Hou et al., 2013). Indeed, organic species such as amines are likely involved during nucleation, as sulfuric acid and ammonia are insufficient to explain nucleation (Kirkby et al., 2011). Nonetheless, sulfuric acid appears to be the key chemical component, as the nucleation rate in both laboratory and field measurements frequently depends on the sulfuric acid concentration (Kuang et al., 2008; Metzger et al., 2010; Nieminen et al., 2009).

While much progress has been made in understanding the mechanisms underlying nucleation, the chemical mechanisms governing particle growth are less certain (Riipinen et al., 2012). For a nucleated nanoparticle to become climatically relevant, it must grow at a rate that is much higher than the rate at which it is lost due to scavenging (Riipinen et al., 2007; Kuang et al., 2010). It has been shown that expected growth rates based on gas-phase sulfuric acid concentrations usually do not match measured growth rates during ambient NPF, suggesting that other chemical species contribute to growth (Kuang et al., 2010; Smith et al., 2008; Stolzenburg et al., 2005). Chemical composition measurements in the $10-30 \mathrm{~nm}$ size range have implicated a variety of molecular species including sulfate, nitrate, ammonium and organics (Smith et al., 2005, 2008, 2010). Several potential growth channels have been suggested, including growth by aminium salts (Barsanti et al., 2009; Smith et al., 2010; Wang et al., 2010a, b) and by organic matter (Donahue et al., 2011; Monge et al., 2012; Perraud et al., 2012).

However, the extent to which other chemical species contribute to growth is not known, in part because few instruments can provide quantitative chemical composition measurements in the nanoparticle size regime (Bzdek et al., 2012a). This work utilizes the Nano Aerosol Mass Spectrometer (NAMS), a single particle mass spectrometer that provides a quantitative measure of particle composition in the 10-30 nm size range (Wang and Johnston, 2006; Wang et al., 2006; Pennington and Johnston, 2012) to determine quantitatively the contributions of certain chemical species to particle growth during NPF in a remote boreal forest environment. A quantitative understanding of the contributions of various chemical species to particle growth is necessary in order to assess the impact of NPF on CCN levels and climate accurately.

\section{Methods}

\subsection{Instrumentation}

Data presented in this work were obtained with the Nano Aerosol Mass Spectrometer (NAMS). Ambient air was sampled to NAMS from a height of $\sim 4 \mathrm{~m}$ through a $1.27 \mathrm{~cm}$ (O.D.) length of copper tubing at a flow rate of $5 \mathrm{~L} \mathrm{~min}^{-1}$.

NAMS has been described in detail elsewhere (Wang et al., 2006; Wang and Johnston, 2006; Pennington and Johnston, 2012). It consists of six main components: a unipolar charger (Chen and Pui, 1999; McMurry et al., 2009), an aerodynamic lens assembly, a digital ion guide (DIG), a digital ion trap (DIT), Nd:YAG laser and a reflectron time-of-flight (TOF) mass analyzer. Aerosol first passes through the unipolar charger to maximize the fraction of particles that receive a +1 charge and then is sampled into the instrument where particles are collimated and focused with the aerodynamic lens and DIG. Particles are then captured inside the DIT where they are irradiated with a high-energy laser pulse $(532 \mathrm{~nm}$, $200 \mathrm{~mJ}$ pulse $^{-1}$, focused to a spot $<100 \mu \mathrm{m}$ ). The laser pulse forms a plasma that completely disintegrates the particle to form multiply charged atomic ions. The ions are mass analyzed by TOF.

Particle size selection in NAMS is accomplished by selective trapping inside the DIT on the basis of mass-to-charge ratio, which can be related to mass normalized diameter $\left(d_{\mathrm{mn}}\right)$, defined as the diameter of a spherical particle having unit density and the same mass-to-charge ratio as the particle being trapped. For these measurements, NAMS was operated to trap $18 \pm 3 \mathrm{~nm}$ particles (DIT ring electrode frequency of $10 \mathrm{kHz}$ and amplitude of $+504 \mathrm{~V} /-507 \mathrm{~V})$. Other relevant parameters are DIG frequency of $50 \mathrm{kHz}$ and amplitude of $\pm 500 \mathrm{~V}$, field adjusting lens voltage of $-400 \mathrm{~V}$ and einzel lens voltage of $-50 \mathrm{~V}$ (Pennington and Johnston, 2012). The relationship between mass normalized diameter (size selection in NAMS) and mobility diameter $\left(d_{\mathrm{m}}\right.$; size measurement with the differential mobility particle sizer, DMPS) is described by

$d_{\mathrm{mn}}=d_{\mathrm{m}}\left(\frac{\rho}{\rho_{0}}\right)^{1 / 3}$,

where the reference density, $\rho_{0}$, is $1 \mathrm{~g} \mathrm{~cm}^{-3}$. Since carbonaceous matter is the major component of particles in Hyytiälä, the ambient particle density was likely on the order of $1.3 \mathrm{~g} \mathrm{~cm}^{-3}$ (Kuwata et al., 2011) meaning that $d_{\mathrm{mn}}$ and $d_{\mathrm{m}}$ differed by less than $10 \%\left(d_{\mathrm{mn}}\right.$ larger $)$. 
Particle mass spectra consisted of a series of multiply charged atomic ions. Raw spectra were baseline-corrected and the signal intensities integrated over the relevant atomic ions for carbon $(\mathrm{C})$, nitrogen $(\mathrm{N})$, oxygen $(\mathrm{O})$ and sulfur (S) so that the mole fractions of each element in the particle are determined. Note that NAMS does not quantitatively measure the hydrogen content, so it is not included in mole fraction determination. Deconvolution of overlapping signal intensities $\left(\mathrm{C}^{+3}\right.$ and $\mathrm{O}^{+4} ; \mathrm{S}^{+4}$ and $\left.\mathrm{O}^{+2}\right)$ was accomplished by the method of Zordan et al. (2010). After deconvolution, the signal intensities for each element were summed, and the relative values were taken as the mole fraction of each element in the particle. Mole fractions were averaged over all particles analyzed in a 10 min time block corresponding to the DMPS scanning period. If fewer than 20 particles were analyzed, then averaging was performed over multiple time blocks until a minimum of 20 particles was achieved. Performing 20-particle averages simultaneously minimizes random error from non-uniform plasma energetics while maximizing time resolution (Klems and Johnston, 2013). Averaging over multiple time blocks was needed only during periods of very low particle number concentration, which generally occurred at night. In general, elemental mole fractions are measured with NAMS to within $\pm 10 \%$ of the true values (Zordan et al., 2010). Mass fractions of molecular species are determined by combining the appropriate number of atoms (e.g., $\mathrm{S}+4 \mathrm{O}$ for sulfate) and converting from elemental mole fraction to elemental mass fraction.

Qualitative measurements of nanoparticle molecular composition were performed with a thermal desorption chemical ionization mass spectrometer (TDCIMS) (Smith et al., 2010). Composition measurements of accumulation mode particles were performed with the Aerodyne aerosol mass spectrometer (AMS) (DeCarlo et al., 2006).

\subsection{Calculation of effective gas-phase sulfuric acid concentration from measured sulfate mass fraction}

The effective sulfuric acid gas-phase concentration can be calculated from the measured particle-phase mass fraction of sulfate by

$\left[\mathrm{H}_{2} \mathrm{SO}_{4}\right]_{\mathrm{NAMS}}=\frac{2 \mathrm{GR}_{\text {MEAS }}}{v_{1} \bar{c}_{1} \Gamma_{\mathrm{m}}} \times \frac{\rho_{\text {particle }}}{\rho_{\text {sulfate }}}$,

where GR $\mathrm{MEAS}_{\text {is }}$ is the measured growth rate, $v_{1}$ the volume occupied by a hydrated $\mathrm{H}_{2} \mathrm{SO}_{4}$ molecule, $\overline{c_{1}}$ the mean thermal speed of the condensing monomer (Kuang et al., 2010), $\rho_{\text {particle }}$ the density of ambient particles during the time period of interest (estimated to be $1.3 \mathrm{~g} \mathrm{~cm}^{-3}$ ) (Kuwata et al., 2011), $\rho_{\text {sulfate }}$ the density of condensed phase sulfuric acid $\left(1.8 \mathrm{~g} \mathrm{~cm}^{-3}\right)$, and $\Gamma_{\mathrm{m}}=\frac{1}{\mathrm{MF}_{\text {sulfate }}}$, where $\mathrm{MF}_{\text {sulfate }}$ is the average sulfate mass fraction for the time period of interest (Bzdek et al., 2012b). Equation (2) does not include the Fuchs-Sutugin correction for mass flux. Although in some circumstances the magnitude of this correction can be sub- stantial (Nieminen et al., 2010), in the particle size range considered here it would affect the calculated sulfuric acid concentration by $<5 \%$, which is much smaller than the uncertainty of the experimental measurements. Equation (2) is only applicable for determination of the gas-phase sulfuric acid concentration when there is a growing mode diameter. Note that since $\Gamma_{\mathrm{m}}$ is determined from an average composition measurement, it accounts for all growth and evaporation processes that occur in the particle phase over the averaging period.

\section{Results and discussion}

In this study, NAMS (Wang and Johnston, 2006; Zordan et al., 2008, 2010; Bzdek et al., 2011, 2012b, 2013b; Pennington and Johnston, 2012; Pennington et al., 2012; Wang et al., 2006) is used to obtain single particle mass spectra during NPF in Hyytiälä, Finland, from 21 March through 24 April 2011. NAMS provides a quantitative measure of nanoparticle elemental composition and in this study was set to analyze particles between 15 and $22 \mathrm{~nm}$ in diameter. The elemental composition allows the mass fractions of sulfate, ammonium and carbonaceous matter to be determined. Example particle formation events are shown in Fig. 1.

Figure 1a shows particle size distributions from 3 to $100 \mathrm{~nm}$ over two consecutive days where NPF was observed, 18 and 19 April 2011. HYSPLIT (Draxler and Rolph, 2013) back trajectories indicate that air masses during this time period were relatively pollution-free, coming from the northwest. Solar irradiance is shown in Fig. 1b along with the NAMS hit rate (number of particles analyzed per $10 \mathrm{~min}$ period), which gives a qualitative measure of the particle number concentration within the size range analyzed. Both events were initiated during the daylight hours. On the first day, the particle growth rate was relatively slow and the mode diameter of the particle size distribution reached the NAMS size range near dusk. On the second day, the growth rate was faster and the mode diameter passed completely through the NAMS size range during the day.

Figure 1c shows the average elemental composition of 15$22 \mathrm{~nm}$ diameter particles as a function of time. The predominant elements in these particles are carbon, nitrogen, oxygen and sulfur. The carbon mole fraction is anti-correlated with the other elements, which has been observed in urban locations as well (Pennington et al., 2012; Klems et al., 2012). This anti-correlation arises because carbon is associated with organic species in the particle, whereas nitrogen and sulfur are associated with inorganic components of the particle (e.g., sulfate, ammonium and possibly nitrate). During NPF, the sulfur and nitrogen mole fractions are larger and the carbon mole fraction is smaller than immediately before or after each event. A similar dependence of elemental mole fraction was noted previously for NPF in other locations (Bzdek et al., 2011, 2012b). Note, however, that whereas the 
a)

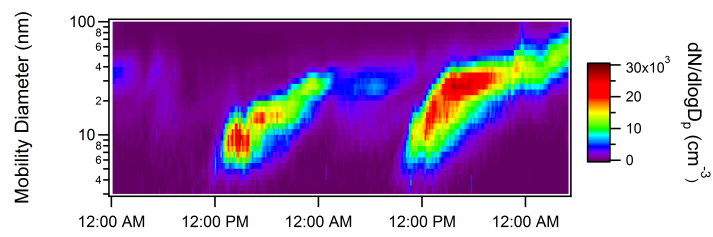

b)

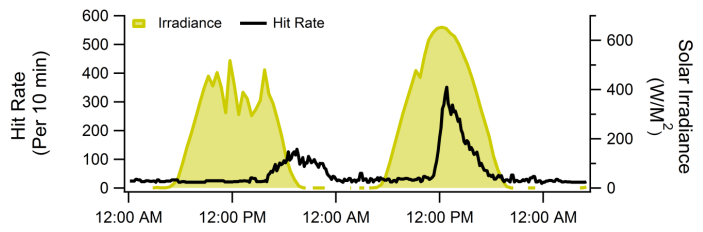

c)

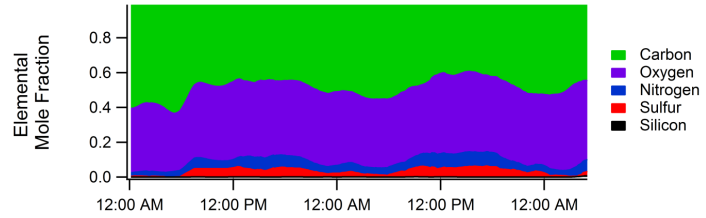

d)

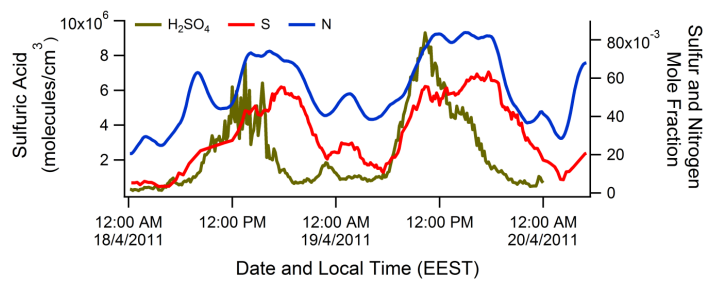

Fig. 1. (a) Particle size distributions for 18 and 19 April 2011. Yellow dashed lines indicate approximate size range analyzed by NAMS. (b) Observed NAMS hit rate (particles analyzed per 10 min period; black) and solar irradiation (yellow). (c) Elemental mole fractions measured by NAMS, averaged over 10 min periods; plots were subjected to 10-point boxcar smoothing. (d) NAMSmeasured sulfur mole fraction (red) and nitrogen mole fraction (blue) and CIMS-measured gas-phase sulfuric acid concentration (yellow-green). Mole fraction plots were subjected to 10-point boxcar smoothing.

relative concentrations of $\mathrm{S}$ and $\mathrm{C}$ are anti-correlated, the $a b$ solute amounts of particulate $\mathrm{S}$ and $\mathrm{C}$ both increase substantially during NPF because there is a substantial increase in nanoparticle mass. A remarkable feature of Fig. 1c is that the change in elemental composition occurs at the onset of NPF before the mode diameter reaches the NAMS size range. This characteristic is shown in more detail in Fig. 1d, where the $\mathrm{N}$ and $\mathrm{S}$ mole fractions are plotted as a function of time. Also shown for reference in Fig. 1d is the gas-phase sulfuric acid concentration measured with a chemical ionization mass spectrometer (CIMS) (Eisele and Tanner, 1993; Petäjä et al., 2009), which closely follows solar irradiance. At the onset of NPF (defined here as the time when the gas-phase sulfuric acid concentration quickly increases), the particle-phase sulfur mole fraction increases almost simultaneously with the gas-phase sulfuric acid concentration. This observation is noteworthy for two reasons. First, it quantifies the change in composition of the condensational sink that results from changing gas-phase concentrations at the onset of NPF. Sec- ond, it shows how changes in nanoparticle chemical composition do not necessarily coincide with changes in nanoparticle mass or number concentration. Near the end of the event, both gas-phase sulfuric acid and particle-phase sulfur mole fraction decrease, but the change in particle composition lags the change in gas-phase concentration by $3-4 \mathrm{~h}$. This slow decline in particle-phase sulfur after gas-phase sulfuric acid declines suggests the event is a regional event rather than a local (plume) event. These observations are consistent with recent measurements of NPF at a rural/coastal site (Bzdek et al., 2013b).

It is reasonable to assume all of the sulfur in these particles exists in the form of sulfate (Bzdek et al., 2012b). First, off-line and on-line molecular composition analyses of collected ultrafine particles in this location show sulfate as a major constituent in nanoparticles, with little to no contribution from other sulfur-containing species (Smith et al., 2010). Second, although organosulfates have been detected in 50 $100 \mathrm{~nm}$ diameter particles in some environments (Hatch et al., 2011), quantitative measurement of its contribution to sub-100 nm particles shows that it is low (Lukács et al., 2009). Moreover, if organosulfates are present in these particles, they are probably the result of aqueous-phase secondary processing of sulfate already contained in the particle and would be most significant during nighttime, rather than during daytime when the increase in sulfur mole fraction occurs. Even if organosulfates exist in the particle, assigning sulfur from an organosulfate to inorganic sulfate will give a correct measure of total sulfate. Finally, S(IV) compounds such as dissolved $\mathrm{SO}_{2}$, bisulfite and sulfite, which may be significant in large particles such as cloud and fog droplets (FinlaysonPitts and Pitts, 2000) or mineral dust (Higashi and Takahashi, 2009; Usher et al., 2003), are unlikely to constitute a significant fraction of sulfur species in ultrafine aerosol (Kerminen et al., 2000).

With the assumption that all sulfur in these particles can be assigned to sulfate, the sulfate mass fraction can be quantitatively determined from the sulfur mole fraction and compared to the measured ambient sulfuric acid concentration. At the onset of NPF each day, the sulfate mass fraction rises quickly from around $5 \%$ to $30 \%$, which corresponds to an increase of the sulfur mole fraction from $\sim 0.01$ to 0.04 (see Fig. 1d). If a preexisting particle at $20 \mathrm{~nm}$ containing a sulfate mass fraction of $5 \%$ grows by sulfuric acid condensation at the measured ambient concentration level, it would take $<3 \mathrm{~h}$ to increase the sulfate mass fraction from $5 \%$ to $30 \%$, which is within the approximate time period for which this change occurs. (Note that the change in particle size for this level of sulfate mass growth would be about $2 \mathrm{~nm}$, so the growing particle would remain within the NAMS size range.) Therefore, sulfuric acid condensation is a reasonable explanation for the rapid rise in sulfur mole fraction each day. A corollary to this conclusion is that the condensation rate of other chemical species (e.g., carbonaceous matter) during this time period early in the event must be small relative to sulfuric acid 
Table 1. Particle growth rate (measured over the period of growth from $10-20 \mathrm{~nm}$ diameter), sulfate mass fraction (averaged over the period when the mode diameter was in the NAMS size range, $\sim 20 \mathrm{~nm}$ diameter), calculated sulfuric acid concentration ([ $\left.\mathrm{H}_{2} \mathrm{SO}_{4}\right]_{\mathrm{NAMS}}$, from Eq. 2 ) and measured sulfuric acid concentration $\left(\left[\mathrm{H}_{2} \mathrm{SO}_{4}\right]_{\text {CIMS }}\right.$, averaged over the period of growth from 10$20 \mathrm{~nm}$ ) for particle formation events on 18 and 19 April 2011.

\begin{tabular}{|c|c|c|}
\hline & 18 April 2011 & 19 April 2011 \\
\hline Growth rate $\left(\mathrm{nm} \mathrm{h}^{-1}\right)$ DMPS $^{\mathrm{a}}$ & $1.2 \pm 0.1$ & $3.0 \pm 0.4$ \\
\hline Sulfate mass fraction ${ }_{\text {NAMS }}{ }^{\mathrm{a}}$ & $0.27 \pm 0.08$ & $0.35 \pm 0.11$ \\
\hline$\left[\mathrm{H}_{2} \mathrm{SO}_{4}\right]_{\text {NAMS }}\left(\text { molec cm }^{-3}\right)^{\mathrm{b}}$ & $3 \pm 1 \times 10^{6}$ & $1.0 \pm 0.4 \times 10^{7}$ \\
\hline$\left[\mathrm{H}_{2} \mathrm{SO}_{4}\right]_{\mathrm{CIMS}}\left(\operatorname{molec} \mathrm{cm}^{-3}\right)^{\mathrm{a}}$ & $3 \pm 2 \times 10^{6}$ & $6 \pm 3 \times 10^{6}$ \\
\hline
\end{tabular}

${ }^{\mathrm{a}}$ Experimental measurements; ${ }^{\mathrm{b}}$ calculated from Eq. (2).

condensation. For example, if sulfuric acid represented only $20 \%$ of the total condensation rate, then it would take much longer, on the order of $12-15 \mathrm{~h}$, to increase the sulfate mass fraction to $30 \%$. Since a time lag of this magnitude is not observed between the increases in sulfuric acid concentration and sulfur mole fraction, mass growth of preexisting particles at the onset of NPF occurs primarily by sulfuric acid condensation. This observation is consistent with a previous AMS measurement of NPF at larger particle diameters, as sulfate was the first species whose particle-phase concentration increased during the event (Q. Zhang et al., 2004).

Table 1 gives, for each event, the measured particle growth rate and sulfate mass fraction, as well as the effective sulfuric acid gas-phase concentration calculated from the particlephase sulfate mass fraction $\left(\left[\mathrm{H}_{2} \mathrm{SO}_{4}\right]_{\text {NAMS }}\right)$ and the measured average sulfuric acid concentration $\left(\left[\mathrm{H}_{2} \mathrm{SO}_{4}\right]_{\mathrm{CIMS}}\right)$. Measuring particle composition at $20 \mathrm{~nm}$ diameter informs about processes operative during growth from 10 to $20 \mathrm{~nm}$, since $\sim 90 \%$ of the particle mass was gained during this period. Therefore, the particle growth rate and $\left[\mathrm{H}_{2} \mathrm{SO}_{4}\right]_{\mathrm{CIMS}}$ were averaged over the time period that the mode diameter increased from 10 to $20 \mathrm{~nm}$, whereas sulfate mass fraction was averaged over the time period that the mode diameter was within the size range analyzed by NAMS $(\sim 18-22 \mathrm{~nm})$. For both NPF events, the calculated sulfuric acid concentration $\left(\left[\mathrm{H}_{2} \mathrm{SO}_{4}\right]_{\text {NAMS }}\right)$ is consistent with the range of measured sulfuric acid concentrations $\left(\left[\mathrm{H}_{2} \mathrm{SO}_{4}\right]_{\mathrm{CIMS}}\right)$. The similarity between calculated and measured sulfuric acid concentrations confirms the link between particle-phase sulfate mass fraction and the rate of gas-phase sulfuric acid condensation. In other words, sulfuric acid uptake into the particles is approximately collision-rate-limited. An important corollary is that existing models are sufficient to describe the uptake of sulfuric acid to growing nanoparticles.

Similar time-dependent changes in the composition of $20 \mathrm{~nm}$ particles are observed in all eight particle formation events observed during this campaign, as shown in Fig. 2. (The yellow shaded regions in Fig. 2 show the approximate time periods for particle growth through the measured size range, as given by particle hit rates with NAMS.) For seven out of eight events, the sulfur mole fraction increases before the particle mode diameter enters the NAMS size range and then decreases as the mode diameter grows past this range. The change in nitrogen mole fraction is highly correlated with sulfur mole fraction $(r=0.83)$ (Fig. 2b), suggesting that nitrogen incorporation is determined primarily by the sulfur content. The likely form of this nitrogen during NPF is ammonium ion. Inorganic nitrate and organic amines can be discounted for several reasons. First, the Aerosol Inorganics Model (AIM) (Clegg et al., 1998) predicts for both solid and liquid condensed phases in the range of temperatures and relative humidities of this study that particulate nitrate will be present only when the ammonium concentration is greater than twice the sulfate concentration. This condition is not met during any of the NPF events since the N/S mole ratio during these time periods averages around 1.5 and never reaches 2 . Inorganic nitrate, however, cannot be ruled out during some off-event nighttime periods where the $\mathrm{N} / \mathrm{S}$ mole ratio exceeds 2 . Second, chemical composition measurements of accumulation mode particles with AMS during these events show that the nitrate to sulfate mole ratios are all below 0.1 (average 0.06), and there is little evidence of aliphatic amines. Third, chemical composition measurements with TDCIMS (Smith et al., 2010) in the same particle size range as NAMS, available only for 18-19 April, show no evidence of inorganic nitrate. Gas-phase amines were not monitored during this campaign. These observations, combined with the strong positive correlation between nitrogen and sulfur in Fig. 2b, suggest that essentially all nitrogen is in the form of ammonium. Although the thermodynamic end point predicted by AIM is fully neutralized ammonium sulfate, only partial neutralization of sulfate is observed during the eight NPF events. Partial neutralization suggests either a kinetic barrier to ammonium incorporation, for example due to an activation barrier for ammonia uptake (Bzdek et al., 2013a), or a modification of the thermodynamic end point by the Kelvin effect. In contrast, AMS measurements of accumulation mode particles show that they are fully neutralized during NPF (ammonium / sulfate mole ratio $\approx 2$ ) as predicted by AIM and indicating that sufficient ammonia levels existed to neutralize sulfuric acid fully in accumulation mode particles. During these NPF events, sulfuric acid concentrations ranged from mid $-10^{6}$ to low $10^{7}$ molecules $\mathrm{cm}^{-3}$, whereas ammonia concentrations ranged from mid- $10^{8}$ to low $10^{9}$ molecules $\mathrm{cm}^{-3}$ (Hakola and Makkonen, unpublished results), confirming that ammonia concentrations were sufficient to neutralize sulfuric acid.

Figure $2 \mathrm{c}$ shows that the carbon mole fraction is anticorrelated with nitrogen $(r=-0.91)$, sulfur $(r=-0.87)$ and oxygen $(r=-0.81)$. The carbon mole fraction is high at night when the sulfur mole fraction is low and then decreases (in relative terms) during the day when NPF occurs. The chemical composition of $20 \mathrm{~nm}$ particles is clearly different at night (when particle number concentrations are only on the 
a)

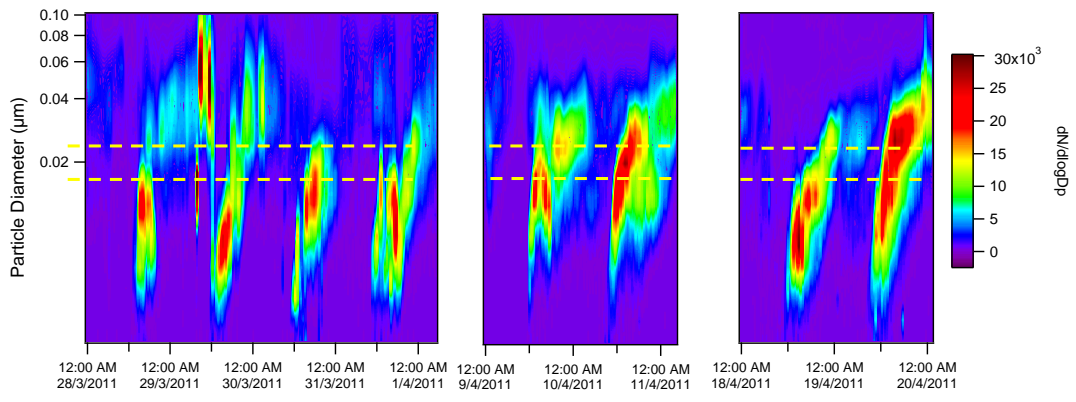

b)

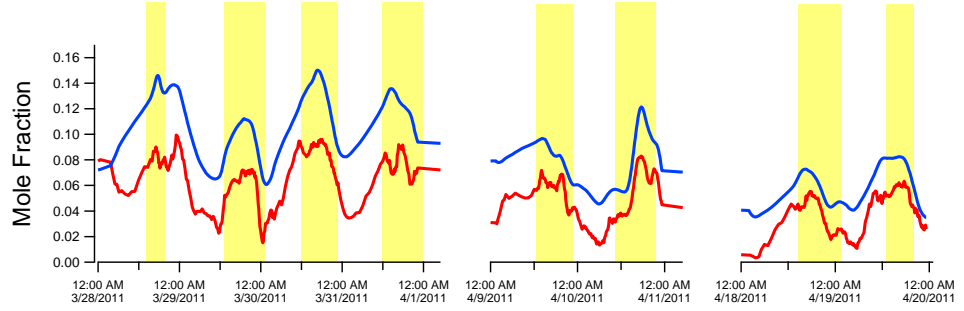

c)
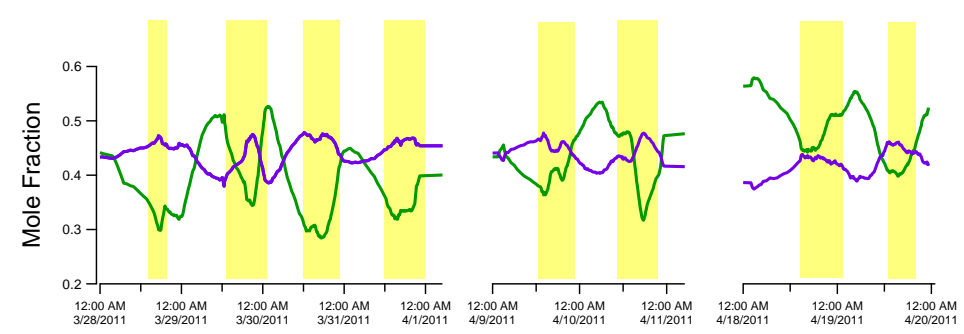

d)

Event Periods

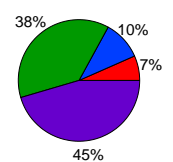

Morning of

Event Days

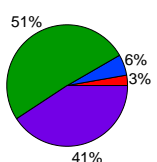

Morning of Non-Event Days

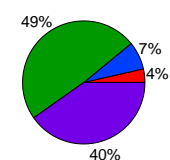

Afternoon/Evenings of Non-Event Days

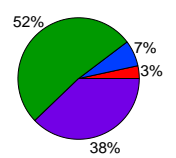

Fig. 2. (a) Particle size distributions for eight days when NPF occurred. (b) Elemental mole fractions of nitrogen (blue) and sulfur (red). (c) Elemental mole fractions of carbon (green) and oxygen (violet). Elemental mole fractions were subjected to 10-point boxcar smoothing; shaded regions show approximate time periods when the particle mode diameter was within the NAMS size range. (d) Average elemental compositions of particles sampled during NPF events, in the mornings of event days (02:00-09:00 LT), in the mornings of non-event days (02:00-09:00) and in the afternoons/evenings of non-event days (10:00-22:00).

order of a few hundred per $\mathrm{cm}^{3}$ ) than during the day when NPF occurs (and particle number concentrations increase to a few thousand per $\mathrm{cm}^{3}$ ). Another trend in Fig. $2 \mathrm{c}$ is that carbon content generally increases from left to right (beginning to end of the measurement period), while sulfur and nitrogen both decrease. In Fig. 2d, the average elemental composition during NPF (average over the yellow shaded periods in Fig. $2 b$ and c) is compared to averages over three non-event time periods: (1) morning hours on event days before NPF begins, (2) morning hours on non-event days and (3) afternoon/evening hours on non-event days. Within experimental error, the elemental compositions during the three off-event time periods are the same. In contrast, the elemental composition of nanoparticles during NPF is substantially different from composition during these three other time periods. In particular, S mole fraction increases by $>100 \%$ and $\mathrm{N}$ mole fraction by $50 \%$, whereas $\mathrm{C}$ mole fraction decreases by about $30 \%$. One implication of these observations is that diurnal trends in nanoparticle chemical composition at this location are not as pronounced on non-NPF days as on NPF days. This is in contrast to another study of NPF in a rural/coastal environment where substantial diurnal trends in nanoparticle composition were measured on both NPF and non-NPF days, although the chemical species enhanced on each type of day were different (Bzdek et al., 2013b).

Figure 3a shows the mass fractions of ammonium, sulfate and carbonaceous matter for $20 \mathrm{~nm}$ particles during NPF, averaged over each of the eight shaded time periods in Fig. 2. 
a)

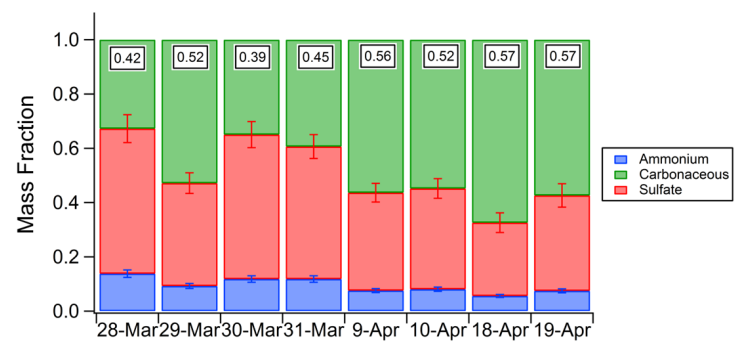

b)

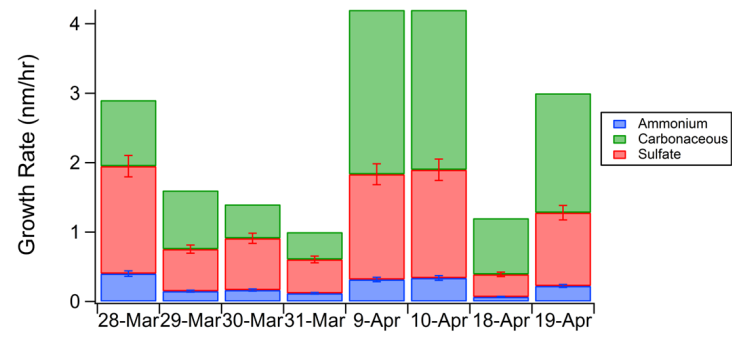

Fig. 3. (a) Mass fractions of sulfate, ammonium and carbonaceous matter for eight NPF events during the measurement campaign. The numerical value inset in each bar is the $\mathrm{O} / \mathrm{C}$ ratio for that event period. (b) Mass growth rates of sulfate, ammonium and carbonaceous matter for the same NPF events. Molecular composition uncertainties are based on assigned uncertainties for measurement of elemental nitrogen and sulfur $(10 \%)$

Ammonium and sulfate are given by nitrogen and sulfur mole fractions as described above. Carbonaceous matter is given by all carbon in the particles plus the portion of oxygen that is not assigned to sulfate. In the early portion of this study, ammonium and sulfate together represent almost two-thirds of the total mass growth, and their contribution decreases to less than half of the mass growth at the end of this study. The remaining mass growth is associated with carbonaceous matter. The increasing contribution of carbonaceous matter during the study parallels increases in biological production of volatile organic carbon as plant growth begins in the spring (Hakola et al., 2012). The apparent oxygen to carbon (O/C) mole ratios for carbonaceous matter are given as insets in Fig. 3a. These values range from 0.4 to 0.6 , which is characteristic of "fresh" secondary organic aerosol (SOA) from biogenic sources (Jimenez et al., 2009). The presence of fresh SOA in these particles is not surprising since the fast particle growth rate leaves little time for oxidative aging. The high contribution of carbonaceous matter to aerosol growth is consistent with previous measurements of aerosol composition with AMS in Hyytiälä (Allan et al., 2006; Raatikainen et al., 2010).

Figure $3 \mathrm{~b}$ shows particle compositions scaled to total growth rate for each of these events. These graphs show that the difference in growth rate from one event to another is caused by a change in the growth rate of all three types of matter together (ammonium, sulfate, carbonaceous matter) and not simply by one of these alone. This observation sug- gests that growth by all three types of matter is driven by photochemistry and/or atmospheric conditions in a similar manner. The differences among absolute growth rates in Fig. $3 b$ are much greater than the differences among relative growth rates in Fig. 3a.

\section{Conclusions}

This study shows that particle growth in the $20 \mathrm{~nm}$ size range during NPF in the Finnish boreal forest springtime occurs by two major pathways: (1) condensation of sulfuric acid with concurrent partial neutralization by ammonia and (2) formation of "fresh" SOA. The extent to which these two pathways contribute to nanoparticle growth is quantified for the first time. Additionally, sulfuric acid condensation is shown to impact substantially the composition of preexisting nanoparticles not associated with the formation event. The relative importance of SOA increases as biological activity in the local environment increases. Nitrogen and sulfur mole fractions in these particles are highly correlated, suggesting that mass growth by ammonia uptake is driven by sulfuric acid condensation. However, these particles are acidic and do not reach the thermodynamic end point of full neutralization to sulfate. In order to understand springtime NPF more thoroughly, future research should be directed toward chemical processes governing sulfate neutralization and acid-catalyzed SOA formation in particles where the Kelvin effect may be substantial.

Acknowledgements. M. V. Johnston acknowledges funding from the US National Science Foundation (NSF) under grant number CHE-1110554. M. Kulmala acknowledges funding from ERC Advanced Grant "ATMNUCLE" (no. 22746) and the Academy of Finland Centre of Excellence program (project no. 1118615). J. N. Smith acknowledges support from the Saastamoinen Foundation and US Department of Energy, grant DE-FG-02-05ER63997. L. Hildebrandt Ruiz acknowledges support from the US NSF under grant number 1137757. The National Center for Atmospheric Research is sponsored by the US NSF. B. R. Bzdek acknowledges graduate fellowships from the University of Delaware Center for Critical Zone Research and EPA STAR (FP-91731501). This publication has not been formally reviewed by EPA, and the views expressed are solely those of the authors. EPA does not endorse any products or commercial services mentioned in this publication.

Edited by: F. Keutsch 


\section{References}

Allan, J. D., Alfarra, M. R., Bower, K. N., Coe, H., Jayne, J. T., Worsnop, D. R., Aalto, P. P., Kulmala, M., Hyötyläinen, T., Cavalli, F., and Laaksonen, A.: Size and composition measurements of background aerosol and new particle growth in a Finnish forest during QUEST 2 using an Aerodyne Aerosol Mass Spectrometer, Atmos. Chem. Phys., 6, 315-327, doi:10.5194/acp-6-315-2006, 2006.

Ball, S. M., Hanson, D. R., Eisele, F. L., and McMurry, P. H.: Laboratory studies of particle nucleation: Initial results for $\mathrm{H}_{2} \mathrm{SO}_{4}$, $\mathrm{H}_{2} \mathrm{O}$, and $\mathrm{NH}_{3}$ vapors, J. Geophys. Res.-Atmos., 104, 2370923718, doi:10.1029/1999jd900411, 1999.

Barsanti, K. C., McMurry, P. H., and Smith, J. N.: The potential contribution of organic salts to new particle growth, Atmos. Chem. Phys., 9, 2949-2957, doi:10.5194/acp-9-2949-2009, 2009.

Benson, D. R., Erupe, M. E., and Lee, S. H.: Laboratorymeasured $\mathrm{H}_{2} \mathrm{SO}_{4}-\mathrm{H}_{2} \mathrm{O}-\mathrm{NH}_{3}$ ternary homogeneous nucleation rates: Initial observations, Geophys. Res. Lett., 36, L15818, doi:10.1029/2009g1038728, 2009.

Berndt, T., Stratmann, F., Sipilä, M., Vanhanen, J., Petäjä, T., Mikkilä, J., Grüner, A., Spindler, G., Lee Mauldin III, R., Curtius, J., Kulmala, M., and Heintzenberg, J.: Laboratory study on new particle formation from the reaction $\mathrm{OH}+\mathrm{SO}_{2}$ : influence of experimental conditions, $\mathrm{H}_{2} \mathrm{O}$ vapour, $\mathrm{NH}_{3}$ and the amine tert-butylamine on the overall process, Atmos. Chem. Phys., 10, 7101-7116, doi:10.5194/acp-10-7101-2010, 2010.

Bzdek, B. R. and Johnston, M. V.: New particle formation and growth in the troposphere, Anal. Chem., 82, 7871-7878, doi:10.1021/ac100856j, 2010.

Bzdek, B. R., Zordan, C. A., Luther, G. W., and Johnston, M. V.: Nanoparticle chemical composition during new particle formation, Aerosol Sci. Tech., 45, 1041-1048, doi:10.1080/02786826.2011.580392, 2011.

Bzdek, B. R., Pennington, M. R., and Johnston, M. V.: Single particle chemical analysis of ambient ultrafine aerosol: A review, J. Aerosol Sci., 52, 109-120, doi:10.1016/j.jaerosci.2012.05.001, 2012a.

Bzdek, B. R., Zordan, C. A., Pennington, M. R., Luther, G. W., and Johnston, M. V.: Quantitative assessment of the sulfuric acid contribution to new particle growth, Environ. Sci. Technol., 46, 4365-4373, doi:10.1021/es204556c, 2012b.

Bzdek, B. R., DePalma, J. W., Ridge, D. P., Laskin, J., and Johnston, M. V.: Fragmentation energetics of clusters relevant to atmospheric new particle formation, J. Am. Chem. Soc., 135, 32763285, doi:10.1021/ja3124509, $2013 \mathrm{a}$.

Bzdek, B. R., Horan, A. J., Pennington, M. R., DePalma, J. W., Zhao, J., Jen, C. N., Hanson, D., Smith, J. N., McMurry, P. H., and Johnston, M. V.: Quantitative and time-resolved nanoparticle composition measurements during new particle formation, Faraday Discuss., doi:10.1039/c3fd00039g, 2013b.

Charlson, R. J., Schwartz, S. E., Hales, J. M., Cess, R. D., Coakley, J. A., Hansen, J. E., and Hofmann, D. J.: Climate forcing by anthropogenic aerosols, Science, 255, 423-430, doi:10.1126/science.255.5043.423, 1992.

Chen, D.-R. and Pui, D. Y. H.: A high efficiency, high throughput unipolar aerosol charger for nanoparticles, J. Nanopart. Res., 1, 115-126, doi:10.1023/a:1010087311616, 1999.
Clegg, S. L., Brimblecombe, P., and Wexler, A. S.: Thermodynamic model of the system $\mathrm{H}^{+}-\mathrm{NH}_{4}^{+}-\mathrm{SO}_{4}^{2-}-\mathrm{NO}_{3}^{-}-\mathrm{H}_{2} \mathrm{O}$ at tropospheric temperatures, J. Phys. Chem. A, 102, 2137-2154, doi:10.1021/jp973042r, 1998.

DeCarlo, P. F., Kimmel, J. R., Trimborn, A., Northway, M. J., Jayne, J. T., Aiken, A. C., Gonin, M., Fuhrer, K., Horvath, T., Docherty, K. S., Worsnop, D. R., and Jimenez, J. L.: Field-deployable, high-resolution, time-of-flight aerosol mass spectrometer, Anal. Chem., 78, 8281-8289, doi:10.1021/ac061249n, 2006.

Donahue, N. M., Trump, E. R., Pierce, J. R., and Riipinen, I.: Theoretical constraints on pure vapor-pressure driven condensation of organics to ultrafine particles, Geophys. Res. Lett., 38, L16801, doi:10.1029/2011g1048115, 2011.

Draxler, R. R., and Rolph, G. D.: HYSPLIT (HYbrid Single-Particle Lagrangian Integrated Trajectory) Model access via NOAA ARL READY Website (http://ready.arl.noaa.gov/HYSPLIT. php), NOAA Air Resources Laboratory, Silver Spring, MD, 2013.

Eisele, F. L. and Tanner, D. J.: Measurement of the gas phase concentration of $\mathrm{H}_{2} \mathrm{SO}_{4}$ and methane sulfonic acid and estimates of $\mathrm{H}_{2} \mathrm{SO}_{4}$ production and loss in the atmosphere, J. Geophys. Res.Atmos., 98, 9001-9010, doi:10.1029/93jd00031, 1993.

Finlayson-Pitts, B. J. and Pitts, J. N.: Chemistry of the Upper and Lower Atmosphere, Academic Press, New York, 2000.

Gong, H., Linn, W. S., Clark, K. W., Anderson, K. R., Sioutas, C., Alexis, N. E., Cascio, W. E., and Devlin, R. B.: Exposures of healthy and asthmatic volunteers to concentrated ambient ultrafine particles in Los Angeles, Inhal. Toxicol., 20, 533-545, doi:10.1080/08958370801911340, 2008.

Hakola, H., Hellén, H., Hemmilä, M., Rinne, J., and Kulmala, M.: In situ measurements of volatile organic compounds in a boreal forest, Atmos. Chem. Phys., 12, 11665-11678, doi:10.5194/acp12-11665-2012, 2012.

Hatch, L. E., Creamean, J. M., Ault, A. P., Surratt, J. D., Chan, M. N., Seinfeld, J. H., Edgerton, E. S., Su, Y., and Prather, K. A.: Measurements of isoprene-derived organosulfates in ambient aerosols by aerosol time-of-flight mass spectrometry - Part 1: Single particle atmospheric observations in Atlanta, Environ. Sci. Technol., 45, 5105-5111, doi:10.1021/es103944a, 2011.

Higashi, M. and Takahashi, Y.: Detection of S(IV) species in aerosol particles using XANES spectroscopy, Environ. Sci. Technol., 43, 7357-7363, doi:10.1021/es900163y, 2009.

Hou, G.-L., Lin, W., Deng, S. H. M., Zhang, J., Zheng, W.J., Paesani, F., and Wang, X.-B.: Negative ion photoelectron spectroscopy reveals thermodynamic advantage of organic acids in facilitating formation of bisulfate ion clusters: Atmospheric implications, J. Phys. Chem. Lett., 779-785, doi:10.1021/jz400108y, 2013.

Jimenez, J. L., Canagaratna, M. R., Donahue, N. M., Prevot, A. S. H., Zhang, Q., Kroll, J. H., DeCarlo, P. F., Allan, J. D., Coe, H., Ng, N. L., Aiken, A. C., Docherty, K. S., Ulbrich, I. M., Grieshop, A. P., Robinson, A. L., Duplissy, J., Smith, J. D., Wilson, K. R., Lanz, V. A., Hueglin, C., Sun, Y. L., Tian, J., Laaksonen, A., Raatikainen, T., Rautiainen, J., Vaattovaara, P., Ehn, M., Kulmala, M., Tomlinson, J. M., Collins, D. R., Cubison, M. J., Dunlea, E. J., Huffman, J. A., Onasch, T. B., Alfarra, M. R., Williams, P. I., Bower, K., Kondo, Y., Schneider, J., Drewnick, F., Borrmann, S., Weimer, S., Demerjian, K., Salcedo, D., Cottrell, L., Griffin, R., Takami, A., Miyoshi, T., 
Hatakeyama, S., Shimono, A., Sun, J. Y., Zhang, Y. M., Dzepina, K., Kimmel, J. R., Sueper, D., Jayne, J. T., Herndon, S. C., Trimborn, A. M., Williams, L. R., Wood, E. C., Middlebrook, A. M., Kolb, C. E., Baltensperger, U., and Worsnop, D. R.: Evolution of organic aerosols in the atmosphere, Science, 326, 1525-1529, doi:10.1126/science.1180353, 2009.

Kerminen, V. M., Pirjola, L., Boy, M., Eskola, A., Teinila, K., Laakso, L., Asmi, A., Hienola, J., Lauri, A., Vainio, V., Lehtinen, K., and Kulmala, M.: Interaction between $\mathrm{SO}_{2}$ and submicron atmospheric particles, Atmos. Res., 54, 41-57, doi:10.1016/s01698095(00)00038-7, 2000.

Kerminen, V. M., Lihavainen, H., Komppula, M., Viisanen, Y., and Kulmala, M.: Direct observational evidence linking atmospheric aerosol formation and cloud droplet activation, Geophys. Res. Lett., 32, L14803, doi:10.1029/2005g1023130, 2005.

Kirkby, J., Curtius, J., Almeida, J., Dunne, E., Duplissy, J., Ehrhart, S., Franchin, A., Gagne, S., Ickes, L., Kurten, A., Kupc, A., Metzger, A., Riccobono, F., Rondo, L., Schobesberger, S., Tsagkogeorgas, G., Wimmer, D., Amorim, A., Bianchi, F., Breitenlechner, M., David, A., Dommen, J., Downard, A., Ehn, M., Flagan, R. C., Haider, S., Hansel, A., Hauser, D., Jud, W., Junninen, H., Kreissl, F., Kvashin, A., Laaksonen, A., Lehtipalo, K., Lima, J., Lovejoy, E. R., Makhmutov, V., Mathot, S., Mikkila, J., Minginette, P., Mogo, S., Nieminen, T., Onnela, A., Pereira, P., Petäjä, T., Schnitzhofer, R., Seinfeld, J. H., Sipila, M., Stozhkov, Y., Stratmann, F., Tome, A., Vanhanen, J., Viisanen, Y., Vrtala, A., Wagner, P. E., Walther, H., Weingartner, E., Wex, H., Winkler, P. M., Carslaw, K. S., Worsnop, D. R., Baltensperger, U., and Kulmala, M.: Role of sulphuric acid, ammonia and galactic cosmic rays in atmospheric aerosol nucleation, Nature, 476, 429-433, doi:10.1038/nature10343, 2011.

Klems, J. P. and Johnston, M. V.: Origin and impact of particle-toparticle variations in composition measurements with the nanoaerosol mass spectrometer, Anal. Bioanal. Chem., 405, 69957003, doi:10.1007/s00216-013-6800-x, 2013.

Klems, J. P., Pennington, M. R., Zordan, C. A., McFadden, L., and Johnston, M. V.: Apportionment of motor vehicle emissions from fast changes in number concentration and chemical composition of ultrafine particles near a roadway intersection, Environ. Sci. Technol., 45, 5637-5643, doi:10.1021/es104228q, 2011.

Klems, J. P., Zordan, C. A., Pennington, M. R., and Johnston, M. V.: Chemical composition of ambient nanoparticles on a particle-by-particle basis, Anal. Chem., 84, 2253-2259, doi:10.1021/ac202868h, 2012.

Knibbs, L. D., Cole-Hunter, T., and Morawska, L.: A review of commuter exposure to ultrafine particles and its health effects, Atmos. Environ., 45, 2611-2622, doi:10.1016/j.atmosenv.2011.02.065, 2011.

Korhonen, P., Kulmala, M., Laaksonen, A., Viisanen, Y., McGraw, R., and Seinfeld, J. H.: Ternary nucleation of $\mathrm{H}_{2} \mathrm{SO}_{4}, \mathrm{NH}_{3}$, and $\mathrm{H}_{2} \mathrm{O}$ in the atmosphere, J. Geophys. Res.-Atmos., 104, 2634926353, doi:10.1029/1999jd900784, 1999.

Kuang, C., McMurry, P. H., McCormick, A. V., and Eisele, F. L.: Dependence of nucleation rates on sulfuric acid vapor concentration in diverse atmospheric locations, J. Geophys. Res.-Atmos., 113, D10209, doi:10.1029/2007jd009253, 2008.

Kuang, C., Riipinen, I., Sihto, S.-L., Kulmala, M., McCormick, A. V., and McMurry, P. H.: An improved criterion for new particle formation in diverse atmospheric environments, Atmos. Chem. Phys., 10, 8469-8480, doi:10.5194/acp-10-8469-2010, 2010.

Kulmala, M., Pirjola, U., and Makela, J. M.: Stable sulphate clusters as a source of new atmospheric particles, Nature, 404, 66-69, doi:10.1038/35003550, 2000.

Kulmala, M., Vehkamäki, H., Petäjä, T., Dal Maso, M., Lauri, A., Kerminen, V. M., Birmili, W., and McMurry, P. H.: Formation and growth rates of ultrafine atmospheric particles: A review of observations, J. Aerosol Sci., 35, 143-176, doi:10.1016/j.jaerosci.2003.10.003, 2004.

Kulmala, M., Riipinen, I., Sipila, M., Manninen, H. E., Petäjä, T., Junninen, H., Dal Maso, M., Mordas, G., Mirme, A., Vana, M., Hirsikko, A., Laakso, L., Harrison, R. M., Hanson, I., Leung, C., Lehtinen, K. E. J., and Kerminen, V. M.: Toward direct measurement of atmospheric nucleation, Science, 318, 89-92, doi:10.1126/science.1144124, 2007.

Kulmala, M., Kontkanen, J., Junninen, H., Lehtipalo, K., Manninen, H. E., Nieminen, T., Petäjä, T., Sipilä, M., Schobesberger, S., Rantala, P., Franchin, A., Jokinen, T., Järvinen, E., Äijälä, M., Kangasluoma, J., Hakala, J., Aalto, P. P., Paasonen, P., Mikkilä, J., Vanhanen, J., Aalto, J., Hakola, H., Makkonen, U., Ruuskanen, T., Mauldin, R. L., Duplissy, J., Vehkamäki, H., Bäck, J., Kortelainen, A., Riipinen, I., Kurtén, T., Johnston, M. V., Smith, J. N., Ehn, M., Mentel, T. F., Lehtinen, K. E. J., Laaksonen, A., Kerminen, V.-M., and Worsnop, D. R.: Direct observations of atmospheric aerosol nucleation, Science, 339, 943-946, doi:10.1126/science.1227385, 2013.

Kuwata, M., Zorn, S. R., and Martin, S. T.: Using elemental ratios to predict the density of organic material composed of carbon, hydrogen, and oxygen, Environ. Sci. Technol., 46, 787-794, doi:10.1021/es202525q, 2011.

Lee, S. S. and Feingold, G.: Precipitating cloud-system response to aerosol perturbations, Geophys. Res. Lett., 37, L23806, doi:10.1029/2010g1045596, 2010.

Lohmann, U. and Feichter, J.: Global indirect aerosol effects: a review, Atmos. Chem. Phys., 5, 715-737, doi:10.5194/acp-5-7152005, 2005.

Lukács, H., Gelencsér, A., Hoffer, A., Kiss, G., Horváth, K., and Hartyáni, Z.: Quantitative assessment of organosulfates in sizesegregated rural fine aerosol, Atmos. Chem. Phys., 9, 231-238, doi:10.5194/acp-9-231-2009, 2009.

Maudgalya, T., Genaidy, A., Weckman, G., Shell, R., Karwowski, W., and Wallace, S.: A critical appraisal of epidemiological studies investigating the effects of ultrafine particles on human health, Hum. Factor. Ergon. Man., 18, 358-373, doi:10.1002/hfm.20115, 2008.

McMurry, P. H., Ghimire, A., Ahn, H.-K., Sakurai, H., Moore, K., Stolzenburg, M., and Smith, J. N.: Sampling nanoparticles for chemical analysis by low resolution electrical mobility classification, Environ. Sci. Technol., 43, 4653-4658, doi:10.1021/es8029335, 2009.

Merikanto, J., Spracklen, D. V., Mann, G. W., Pickering, S. J., and Carslaw, K. S.: Impact of nucleation on global CCN, Atmos. Chem. Phys., 9, 8601-8616, doi:10.5194/acp-9-8601-2009, 2009.

Metzger, A., Verheggen, B., Dommen, J., Duplissy, J., Prevot, A. S. H., Weingartner, E., Riipinen, I., Kulmala, M., Spracklen, D. V., Carslaw, K. S., and Baltensperger, U.: Evidence for the role of organics in aerosol particle formation under atmo- 
spheric conditions, Proc. Natl. Acad. Sci. USA, 107, 6646-6651, doi:10.1073/pnas.0911330107, 2010.

Monge, M. E., Rosenorn, T., Favez, O., Muller, M., Adler, G., Riziq, A. A., Rudich, Y., Herrmann, H., George, C., and D'Anna, B.: Alternative pathway for atmospheric particles growth, Proc. Natl. Acad. Sci. USA, 109, 6840-6844, doi:10.1073/pnas.1120593109, 2012.

Nieminen, T., Manninen, H. E., Sihto, S. L., Yli-Juuti, T., Mauldin, R. L., Petäjä, T., Riipinen, I., Kerminen, V. M., and Kulmala, M.: Connection of sulfuric acid to atmospheric nucleation in boreal forest, Environ. Sci. Technol., 43, 4715-4721, doi:10.1021/es803152j, 2009.

Nieminen, T., Lehtinen, K. E. J., and Kulmala, M.: Sub-10 nm particle growth by vapor condensation - effects of vapor molecule size and particle thermal speed, Atmos. Chem. Phys., 10, 97739779, doi:10.5194/acp-10-9773-2010, 2010.

Oberdörster, G., Oberdörster, E., and Oberdörster, J.: Nanotoxicology: An emerging discipline evolving from studies of ultrafine particles, Environ. Health Persp., 113, 823-839, doi:10.1289/ehp.7339, 2005.

Pennington, M. R. and Johnston, M. V.: Trapping charged nanoparticles in the Nano Aerosol Mass Spectrometer (NAMS), Int. J. Mass Spectrom., 311, 64-71, doi:10.1016/j.ijms.2011.12.011, 2012.

Pennington, M. R., Klems, J. P., Bzdek, B. R., and Johnston, M. V.: Nanoparticle chemical composition and diurnal dependence at the CalNex Los Angeles ground site, J. Geophys. Res.-Atmos., 117, D00V10, doi:10.1029/2011jd017061, 2012.

Perraud, V., Bruns, E. A., Ezell, M. J., Johnson, S. N., Yu, Y., Alexander, M. L., Zelenyuk, A., Imre, D., Chang, W. L., Dabdub, D., Pankow, J. F., and Finlayson-Pitts, B. J.: Nonequilibrium atmospheric secondary organic aerosol formation and growth, Proc. Natl. Acad. Sci. USA, 109, 2836-2841, doi:10.1073/pnas.1119909109, 2012.

Petäjä, T., Mauldin, III, R. L., Kosciuch, E., McGrath, J., Nieminen, T., Paasonen, P., Boy, M., Adamov, A., Kotiaho, T., and Kulmala, M.: Sulfuric acid and $\mathrm{OH}$ concentrations in a boreal forest site, Atmos. Chem. Phys., 9, 7435-7448, doi:10.5194/acp9-7435-2009, 2009.

Raatikainen, T., Vaattovaara, P., Tiitta, P., Miettinen, P., Rautiainen, J., Ehn, M., Kulmala, M., Laaksonen, A., and Worsnop, D. R.: Physicochemical properties and origin of organic groups detected in boreal forest using an aerosol mass spectrometer, Atmos. Chem. Phys., 10, 2063-2077, doi:10.5194/acp-10-20632010, 2010.

Riipinen, I., Sihto, S.-L., Kulmala, M., Arnold, F., Dal Maso, M., Birmili, W., Saarnio, K., Teinilä, K., Kerminen, V.-M., Laaksonen, A., and Lehtinen, K. E. J.: Connections between atmospheric sulphuric acid and new particle formation during QUEST III-IV campaigns in Heidelberg and Hyytiälä, Atmos. Chem. Phys., 7, 1899-1914, doi:10.5194/acp-7-1899-2007, 2007.

Riipinen, I., Yli-Juuti, T., Pierce, J. R., Petäjä, T., Worsnop, D. R., Kulmala, M., and Donahue, N. M.: The contribution of organics to atmospheric nanoparticle growth, Nat. Geosci., 5, 453-458, doi:10.1038/ngeo1499, 2012.

Rosenfeld, D., Lohmann, U., Raga, G. B., O’Dowd, C. D., Kulmala, M., Fuzzi, S., Reissell, A., and Andreae, M. O.: Flood or drought: How do aerosols affect precipitation?, Science, 321, 1309-1313, doi:10.1126/science.1160606, 2008.
Sipila, M., Berndt, T., Petäjä, T., Brus, D., Vanhanen, J., Stratmann, F., Patokoski, J., Mauldin, R. L., Hyvarinen, A. P., Lihavainen, H., and Kulmala, M.: The role of sulfuric acid in atmospheric nucleation, Science, 327, 1243-1246, doi:10.1126/science.1180315, 2010.

Smith, J. N., Moore, K. F., Eisele, F. L., Voisin, D., Ghimire, A. K., Sakurai, H., and McMurry, P. H.: Chemical composition of atmospheric nanoparticles during nucleation events in Atlanta, J. Geophys. Res.-Atmos., 110, D22S03, doi:10.1029/2005jd005912, 2005.

Smith, J. N., Dunn, M. J., VanReken, T. M., Iida, K., Stolzenburg, M. R., McMurry, P. H., and Huey, L. G.: Chemical composition of atmospheric nanoparticles formed from nucleation in Tecamac, Mexico: Evidence for an important role for organic species in nanoparticle growth, Geophys. Res. Lett., 35, L04808, doi:10.1029/2007gl032523, 2008.

Smith, J. N., Barsanti, K. C., Friedli, H. R., Ehn, M., Kulmala, M., Collins, D. R., Scheckman, J. H., Williams, B. J., and McMurry, P. H.: Observations of aminium salts in atmospheric nanoparticles and possible climatic implications, Proc. Natl. Acad. Sci. USA, 107, 6634-6639, doi:10.1073/pnas.0912127107, 2010.

Stolzenburg, M. R., McMurry, P. H., Sakurai, H., Smith, J. N., Mauldin, R. L., Eisele, F. L., and Clement, C. F.: Growth rates of freshly nucleated atmospheric particles in Atlanta, J. Geophys. Res.-Atmos., 110, D22S05, doi:10.1029/2005jd005935, 2005.

Usher, C. R., Michel, A. E., and Grassian, V. H.: Reactions on mineral dust, Chem. Rev., 103, 4883-4939, doi:10.1021/cr020657y, 2003.

Wang, S. Y. and Johnston, M. V.: Airborne nanoparticle characterization with a digital ion trap-reflectron time of flight mass spectrometer, Int. J. Mass Spectrom., 258, 50-57, doi:10.1016/j.ijms.2006.07.001, 2006.

Wang, S. Y., Zordan, C. A., and Johnston, M. V.: Chemical characterization of individual, airborne sub-10-nm particles and molecules, Anal. Chem., 78, 1750-1754, doi:10.1021/ac0522431, 2006.

Wang, L., Khalizov, A. F., Zheng, J., Xu, W., Ma, Y., Lal, V., and Zhang, R. Y.: Atmospheric nanoparticles formed from heterogeneous reactions of organics, Nat. Geosci., 3, 238-242, doi:10.1021/ac0522431, 2010a.

Wang, L., Lal, V., Khalizov, A. F., and Zhang, R. Y.: Heterogeneous chemistry of alkylamines with sulfuric acid: Implications for atmospheric formation of alkylaminium sulfates, Environ. Sci. Technol., 44, 2461-2465, doi:10.1021/es9036868, 2010b.

Weber, R. J., Marti, J. J., McMurry, P. H., Eisele, F. L., Tanner, D. J., and Jefferson, A.: Measurements of new particle formation and ultrafine particle growth rates at a clean continental site, J. Geophys. Res.-Atmos., 102, 4375-4385, doi:10.1029/96jd03656, 1997.

Young, L. H., Benson, D. R., Kameel, F. R., Pierce, J. R., Junninen, H., Kulmala, M., and Lee, S.-H.: Laboratory studies of $\mathrm{H}_{2} \mathrm{SO}_{4} / \mathrm{H}_{2} \mathrm{O}$ binary homogeneous nucleation from the $\mathrm{SO}_{2}+\mathrm{OH}$ reaction: evaluation of the experimental setup and preliminary results, Atmos. Chem. Phys., 8, 4997-5016, doi:10.5194/acp-84997-2008, 2008

Yu, H., McGraw, R., and Lee, S. H.: Effects of amines on formation of sub-3 nm particles and their subsequent growth, Geophys. Res. Lett., 39, L02807, doi:10.1029/2011g1050099, 2012. 
Zhang, Q., Stanier, C. O., Canagaratna, M. R., Jayne, J. T., Worsnop, D. R., Pandis, S. N., and Jimenez, J. L.: Insights into the chemistry of new particle formation and growth events in Pittsburgh based on aerosol mass spectrometry, Environ. Sci. Technol., 38, 4797-4809, doi:10.1021/es035417u, 2004.

Zhang, R. Y., Khalizov, A., Wang, L., Hu, M., and Xu, W.: Nucleation and growth of nanoparticles in the atmosphere, Chem. Rev., 112, 1957-2011, doi:10.1021/cr2001756, 2012.

Zhang, R. Y., Suh, I., Zhao, J., Zhang, D., Fortner, E. C., Tie, X. X., Molina, L. T., and Molina, M. J.: Atmospheric new particle formation enhanced by organic acids, Science, 304, 1487-1490, doi:10.1126/science.1095139, 2004.

Zhang, R. Y., Wang, L., Khalizov, A. F., Zhao, J., Zheng, J., McGraw, R. L., and Molina, L. T.: Formation of nanoparticles of blue haze enhanced by anthropogenic pollution, Proc. Natl. Acad. Sci. USA, 106, 17650-17654, doi:10.1073/pnas.0910125106, 2009.
Zollner, J. H., Glasoe, W. A., Panta, B., Carlson, K. K., McMurry, P. H., and Hanson, D. R.: Sulfuric acid nucleation: power dependencies, variation with relative humidity, and effect of bases, Atmos. Chem. Phys., 12, 4399-4411, doi:10.5194/acp-12-43992012, 2012.

Zordan, C. A., Wang, S., and Johnston, M. V.: Time-resolved chemical composition of individual nanoparticles in urban air, Environ. Sci. Technol., 42, 6631-6636, doi:10.1021/es800880z, 2008.

Zordan, C. A., Pennington, M. R., and Johnston, M. V.: Elemental composition of nanoparticles with the Nano Aerosol Mass Spectrometer, Anal. Chem., 82, 8034-8038, doi:10.1021/ac101700q, 2010 . 